\title{
"Grieving for Tibet"
}

Conceiving the Modern State in Late-Qing Inner Asia

\section{Patterson Giersch}

\section{OpenEdition}

\section{Journals}

Electronic version

URL: http://journals.openedition.org/chinaperspectives/4013

DOI: 10.4000/chinaperspectives.4013

ISSN: 1996-4617

\section{Publisher}

Centre d'étude français sur la Chine contemporaine

\section{Printed version}

Date of publication: 1 July 2008

Number of pages: 4-18

ISSN: 2070-3449

\section{Electronic reference}

C. Patterson Giersch, " "Grieving for Tibet" », China Perspectives [Online], 2008/3 | 2008, Online since 01 July 2011, connection on 28 October 2019. URL : http://journals.openedition.org/chinaperspectives/ 4013 ; DOI : 10.4000/chinaperspectives.4013

(C) All rights reserved 
C

"Grieving for Tibet"

\author{
Conceiving the Modern State in Late-Qing Inner Asia
}

C. PATTERSON GIERSCH ${ }^{(1)}$

This article explores late Qing (1877-1911) state-building in Inner Asia (Xinjiang, Mongolia, and Tibet) in three ways. It demonstrates how efforts to replace hybrid, imperial institutions with Chinese-style administration were contingent and unpredictable processes. It compares elite-state relations, in Inner Asia and China proper, to explore the diverse impacts on Mongol, Tibetan, and Han elites. Finally, it surveys reform-era (1898-1911) media to reveal how Han elites conceived of Inner Asian territories and peoples in new ways and with enduring consequences.

\section{Introduction}

C hina's encounters with modernity have drawn steady attention from generations of scholars. Recently, historians have begun investigating the transformation from Qing empire to modern Chinese nation state in the ethnically diverse Inner Asian frontier territories (Northeast China, Mongolia, Xinjiang, Qinghai, and Tibet). (2) By 1800 , the Qing entity contained multiple territories and ruling systems. The power to allocate resources, administer justice, or use legitimate force was, in some cases, lodged only tentatively in the central state, which, given its limitations, judiciously delegated authority to hybrid institutions, including the Tibetan Buddhist clergy, Turkic leaders (begs), and the hereditary nobility from Mongol banners. Hybridity defined the high Qing state in the eighteenth century, and there is reason to believe that the Qianlong emperor ( $\mathrm{r}$. 1736-1799) revelled in the diversity of his realm. ${ }^{(3)}$ By the 1820s, however, some Han intellectuals argued for eradicating hybrid institutions and reorganizing frontiers using the institutions of China proper (neidi). The chaos of the midnineteenth century made these plans impractical as state capacity declined in many frontiers. Beginning in the 1870 s, there were strenuous efforts to reverse this trajectory, and it was at this time that some officials fought not just to rebuild state capacity but to claim for the central state the powers that were once delegated to hybrid institutions. The model of centralization chosen, moreover, was China proper's provincial (xingsheng) and county (junxian) system.

In calling for provincial governance in the Inner Asian territories, reformers also sought to transform society. Not only did they wish to replace local elites with ethnic Han officials, they also argued for assimilating non-Han people to Chinese ways, encouraging Han migration into frontier areas, and developing local economic productivity to serve the state. Scholars have pointed to this as a turning point in Chinese history, a point when beleaguered Qing rulers, worn down by rebellion, threatened by foreign imperialism, and on the defensive against Han nationalism, definitively departed from earlier "pluralist" practices of empire in which non-Han had played important roles. ${ }^{(4)}$ What has rarely been emphasised about the "provincialising" (transformation into provinces) of Inner Asian regions is that it was a contested process drawn out over decades. The first territory to be transformed into a province was Xinjiang, in 1884, but it was not until the first decade of the twentieth century that provincialisation was seriously considered for other Inner Asian lands. From 1877, when Zuo Zongtang submitted his first plan for Xinjiang, to 1907, when the court entertained a thorough proposal for provincialising Mongolia, three critical decades passed, decades in which Chinese politics were utterly changed by new ideas about the state and its relations to frontier lands and peoples. In the end, the actual implementation of provincial-style institutions was piecemeal and disrupted by the 1911 revolution. Given these qualifications, it is important to re-evaluate the late Qing approach to Inner Asia.

This paper synthesises recent work on the process of transforming Xinjiang, Mongolia, and Tibet, 1877-1911, and it emphasises three observations designed to provoke contin-

1. I thank Cynthia Chen for research assistance and the Wellesley College Social Science Summer Research Program for funding.

2. For one nice overview, see Joseph Esherick, "How the Qing became China," in Joseph Esherick, et al. (eds), Empire to Nation, Lanham, Md., Rowman and Littlefied. 2006, pp. 229-259. 


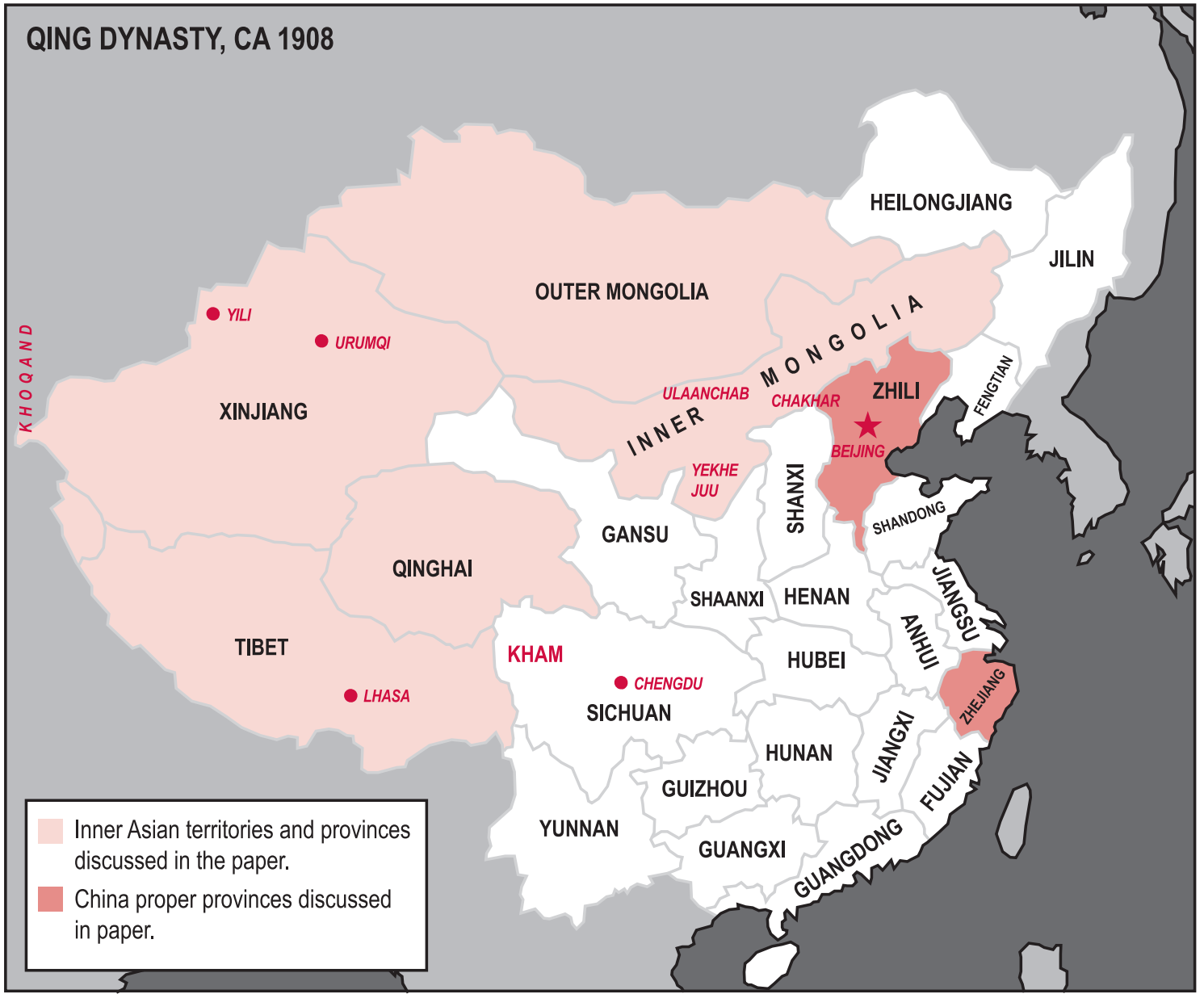

ued debate and inquiry. The first is that the decisions to implement new governing systems in Xinjiang, Mongolia, and Tibet were neither easy nor inevitable. There was opposition, and alternatives were suggested. While we are increasingly aware that the contingent events and choices of the Republican era (1912-1949) structured important changes in ethnic relations, we have not brought the same level of interrogation to the late Qing. We know, for instance, that Republican state-builders imagined Inner Asia as part of the new nation, scholars adopted new techniques for producing knowledge about non-Han peoples, ${ }^{(5)}$ the Communist Party in Yan'an developed policies for dealing with non-Han, ${ }^{(6)}$ and events led to ethnogenesis among some peripheral peoples. ${ }^{(7)}$ However, we are unsure about the historical legacies shaping such developments because the continuities from and ruptures with the late Qing are unclear. It is important, therefore, to treat as contingent the developments in Inner Asia, ca 1877-1911, and to identify any significant features that emerged from those years.

Second, because provincialising policies were designed to reorganise relations between state and elites in Inner Asia, this topic should be studied within the context of state-elite relations, already a well-developed area of inquiry for late Qing China proper. There is good evidence that, in the last decades of Qing rule, the recovery from rebellion and the efforts to increase state capacity created new opportunities for a Han "managerial elite." Elites claimed new roles in administering local society and developed new media for comment on imperial policy. ${ }^{(8)}$ In many cases, there were tensions between state and elite, but at the same time there were also important shared networks and goals. How does this compare to the evolution of relations in frontier areas, where elites were not Han literati but Mongol nobles, Khampa hereditary rulers, or Tibetan-Buddhist lamas? In addition to these comparisons, we must assess the influence of Inner Asia on reformist Han elites. Beginning in the 1890s, the

3. Laura Hostetler, Qing Colonial Enterprise: Ethnography and Cartography in Early Modern China, Chicago, University of Chicago Press, 2001, pp. 41-49.

4. James A. Millward, Eurasian Crossroads: A History of Xinjiang, New York, Columbia University Press, 2007, p. 133; Sudebilige (Shirnuut Sodbilig), Wan Qing zhengfu dui Xinjiang, Menggu, he Xizang zhengce yanjiu, Huhehaote, Nei Menggu renmin chubanshe, 2005, p. 2; Prasenjit Duara, Sovereignty and Authenticity: Manchukuo and the East Asian Modern, Lanham, Rowman \& Littlefield Publishers, 2003, p. 47.

5. Thomas Shawn Mullaney, Coming to Terms with the Nation: Ethnic Classification and Scientific Statecraft in Modern China, 1928-1954, Ph.D. Dissertation, Columbia University, 2006.

6. Xiaoyuan Liu, Frontier Passages: Ethnopolitics and the Rise of Chinese Communism 1921-1945, Washington, D.C., Woodrow Wilson Center Press, distributed by Stanford University Press, 2004.

7. Dru C. Gladney, Dislocating China: Reflections on Muslims, Minorities, and other Subaltern Subjects, Chicago, University of Chicago Press, 2004, pp. 217-218.

8. Mary Rankin, Elite Activism and Political Transformation in China: Zhejiang Province 1865-1911, Stanford, Stanford University Press, 1986; Joan Judge, Print and Politics: 'Shibao' and the Culture of Reform in Late Qing China, Stanford, Stanford University Press, 1996. 
reformist media provided a forum for a new type of "public opinion." What did this nascent public opinion have to say about frontier peoples and territories? This paper makes an initial survey of the reformist press to evaluate emerging discourses about Inner Asian territory and peoples.

Third, the study of late Qing Inner Asia must be placed within the context of recent scholarship that emphasises cognition and modern state-making. Modern state-building is a creative process, both in terms of institutions developed and ideas formulated. Prasenjit Duara's recent work on Manchukuo emphasises that "recognition of a nation was - and is - not merely a political act; it has a cognitive and ontological dimension." (9) If I read him correctly, Duara believes that "latecomers," late-forming nation-states (including China), were confronted with difficult and somewhat unique tasks. To build modern states that fit within the global system, Chinese first sought to maximise territory and militarise boundaries; this meant eradicating "informal arrangements [and] multiple sovereignties" in Inner Asian territories. Even as the state eradicated hybrid institutions, however, it had to represent a diverse and messy post-imperial conglomerate as an integrated whole, where less-civilised frontier and civilised centre shared a common political identity. To create such representations required new intellectual and administrative technologies (ethnologies, surveys, censuses), and Duara argues that Chinese learned these approaches from Japan. Forced to confront Japanese imperialism in Manchukuo, Chinese began to conceive of frontiers as "vital national territories" and to adopt the disciplines of anthropology, history, and geography to locate "these places and people within the national narrative." In the end, Nationalist policy-makers responded by bringing institutionalised anthropology and geography - as well as new schools and censuses - to bear on the challenge of extending administration into frontiers. ${ }^{(10)}$ This is compelling and, I believe, accurate stuff, except for the implication that it was entirely new in the 1930s. In the first decade of the twentieth century, Han elites lamented foreign threats to Inner Asia and developed a symbolic vocabulary to demonstrate how these regions "screened" China proper and made possible the livelihoods of millions. This was an early articulation of the importance of frontiers as national territory, and intellectuals also sought to introduce methods for producing knowledge about the frontiers and their peoples. Certainly anthropology as we know it was not selected, but officials and writers did urge surveys that would examine the exotic traditions of Mongolia and Tibet, and geography was singled out as a critical discipline. The geography considered important, moreover, was not con- tained in traditional Qing gazetteers or travel accounts. Instead, writers specifically identified European practices of surveying and record-keeping as foundations for knowledge and power. These developments, along with the plans for comprehensive Chinese education of Inner Asian youth, suggest that important cognitive transformations were already taking place in the late Qing.

These developments should make us pause to consider the relationship between Inner Asia and the Chinese state. Recently, Rebecca Karl and Peter Zarrow have argued that 1898 marks the onset of a period when "China was compelled to... grapple with the multifaceted crises produced by its forced incorporation into the uneven global system of states, capital, and knowledge." (II) They place the late Qing at the centre of China's initial confrontations with modernity. Similarly, the modern challenges of conceiving a nation in a multi-ethnic empire began not in the Republican period but in the last decades of the Qing. Reformist elites already knew that when it came to knowledge about Inner Asia they were at a disadvantage to foreign powers. The timing of this recognition, moreover, is important, because it gave rise to certain ideas that would shape subsequent developments and, to some degree, influence thinking into the present.

\section{The pluralist empire}

The changes in the late nineteenth century were not the first radical break in China's interaction with Inner Asia. The expansion into those realms was part of a monumental transformation initiated by an early modern "Great Game," pitting the Russians, Qing, and Zunghar Mongols against each other. The Qing desire for security against Russia and the Zunghar federation drove multiple changes within state and economy, and ultimately led to the creation of institutions that carried out and consolidated the conquests of Mongolia, Xinjiang, and Tibet. This was a non-linear, contingent, and controversial process that lasted from Nurhaci's early alliance with Khorcin Mongols in 1626 to the final conquest of Xinjiang in 1759 . $^{(12)}$ It was also a process partially driven

9. Duara, Sovereignty and Authenticity, p. 23.

10. Ibid., pp. 179-180, 187-192, 199-200.

11. Rebecca E. Karl and Peter Zarrow, "Introduction," in Rethinking the 1898 Reform Period: Political and Cultural Change in Late Qing China, Cambridge, Harvard University Asia Center, 2002, p. 7.

12. For "Great Game" and a detailed narrative, see Peter C. Perdue, China Marches West: The Qing Conquest of Central Eurasia, Cambridge, Belknap Press of Harvard University Press, 2005, p. 1, ch. 3-7. For alliances with Mongols, see Johan Elverskog, Our Great Qing: The Mongols, Buddhism, and the State in Late Imperial China, Honolulu, University of Hawai'i Press, 2006, pp. 14, 23-27. 
by the Manchu background of the Qing imperial clan. The Qing and their diverse conquest elite, including Han, Mongols, and Manchu bannermen, originated in the northeastern frontier and brought a unique strategic culture and military capability to ruling China. ${ }^{(13)}$

If Qing empire-builders had their own contingent reasons for expanding into Inner Asia, they also developed, through trial and error, flexible ruling strategies and institutions for each region. These institutions were always evolving, but generally speaking, Qing rule in the Inner Asian regions reflected both a practical approach to ruling diverse peoples and an imperial ideology designed for a multi-cultural empire. Influential Qing empire-builders were often reluctant to seek major changes in local societies, in part because many officials believed that different peoples possessed different "natures" (xing), which justified policies of segregation and adaptation to indigenous institutions. ${ }^{(14)}$ Thus, the Qing often empowered local elites, an approach that certainly modified indigenous political institutions yet also allowed them to endure. In Mongolia and Xinjiang, for instance, the Qing adapted to local legal practices by incorporating aspects of traditional local law. ${ }^{\text {(15) }}$

Not only was the Qing a "pluralist" empire, the Qianlong emperor conceived of himself as much more than the ruler of China. Studies suggest he probably identified at least five distinct subject peoples - Manchu, Mongol, Tibetan, Turkestani, and, of course, Han Chinese - each sharing equal membership in the Qing realm. ${ }^{(16)}$ The Qing were often successful, moreover, in convincing subject peoples of their legitimacy. The court skilfully employed multifaceted and dynamic tactics to attract Mongol support over a period of almost three centuries. Early Qing leaders engaged Mongol concepts of divine power as well as their sense of community (ulus) to construct a Manchu-Mongol alliance. Later, the Qing successfully convinced Mongol elites to embrace membership in banners - bureaucratic systems that transformed mobile, fluid Mongol communities into territorially fixed entities ("banners" and "leagues") under Mongol aristocratic leadership and Qing supervision. Qing rulers, moreover, patronised Tibetan Buddhism in ways that led Mongols to identify being Mongol and Buddhist as naturally connected to being Qing subjects. ${ }^{(17)}$

Mongol loyalty was not always freely given, and coercion was employed throughout Inner Asia. In Qinghai, for example, Tibetan Buddhist monasteries were attacked in order to bring them under control. The state then classified all people, assigning them to distinct groups as a means of segregating them. In the process of delimiting territories and establishing banners for the region's Mongols, for instance, the Khalkas were separat- ed from the Khosots. ${ }^{(18)}$ While Qing policies sought stark segregation in some cases, they also exploited important interconnections. For example, the Qing made Mongols, many of whom practiced Tibetan Buddhism, dependent on Tibetans by outlawing reincarnating lamas from appearing in Mongolia, a policy designed to prevent the aristocracy from dominating both religious and secular institutions. ${ }^{(1)}$

Clearly, Qing rulers sought to control their diverse subjects, but they did not formulate coherent policies designed to assimilate or acculturate them to Chinese ways. While influential Han bureaucrats did, at times, seek to transform and assimilate certain south-western indigenous groups, their efforts were sporadic and often not supported by Manchus and other elite bannermen - the officials responsible for Inner Asian frontiers. ${ }^{(20)}$ In Xinjiang, just as in Mongolia, the Qing adapted to and modified local ruling practices by developing parallel political and legal institutions. In southern Xinjiang, the Qing appointed Turkestani officials (begs) to administer the Turki-speaking population. In eastern Xinjiang, Han civilians were subject to magistrates as they would have been in China proper, but hereditary rulers with princely titles (jasaks) ruled over Mongol communities. ${ }^{(21)}$

In every case, Inner Asian ruling institutions were developed through ongoing processes of trial-and-error. Nowhere is this clearer than in Tibet, where it took decades of conflict before the Qing developed a relatively stable approach. Not until the mid-eighteenth century did the Dalai Lama institution emerge as the key to administering Tibet. At this

13. Perdue, China Marches West, p. 507.

14. For a longer explanation, see Giersch, "Critical Han Studies? The Late Imperial Southwest as Case Study," unpublished ms; for concepts about human nature in Qing China, see Emma Jinhua Teng, Taiwan's Imagined Geography: Chinese Colonial Travel Writing and Pictures, 1683-1895, Cambridge, Harvard University Asia Center, 2004, ch. 4.

15. For Mongol law, see Dorothea Heuschert, "Legal Pluralism in the Qing Empire: Manchu Legislation for the Mongols," The International History Review, vol. 20, no. 2, June 1998, pp. 310-324. For Islamic law, see James A. Millward, Beyond the Pass: Economy, Ethnicity, and Empire in Qing Central Asia, 1759-1864, Stanford, Stanford University Press, 1998, pp. 121-122.

16. Millward, Beyond the Pass, pp. 197-203.

17. Elverskog, Our Great Qing, pp. 3, 24, 45, 61, 126; Sudebilge, pp. 5-12.

18. Perdue, China Marches West, p. 312 and ch. 8 in general.

19. Uradyn E. Bulag, "Going Imperial: Tibeto-Mongolian Buddhism and Nationalism in China and Inner Asia," in Empire to Nation, pp. 262-263.

20. For information on civilising, see Stevan Harrell, "Introduction: Civilizing Projects and the Reaction to Them," in Cultural Encounters on China's Ethnic Frontiers, Seattle, University of Washington Press, 1995, pp. 3-36; Perdue, China Marches West, ch. 9. For discussions of the ascriptive elites and their suspicions of assimilation, see Donald S. Sutton, "Ethnicity and the Miao Frontier in the Eighteenth Century," Empire at the Margins. Culture, Ethnicity, and Frontier in Early Modern China, Pamela Kyle Crossley, et al. (eds), Berkeley, University of California Press, 2006, p. 196 and Table 1.

21. Millward, Beyond the Pass, pp. 32-33. 
time, the Dalai Lama and his councillors (bka'-blon) came to exercise significant ecclesiastical and secular powers, but did so under the supervision of two Qing imperial residents (ambans) and a Qing garrison. ${ }^{(22)}$ The Dalai Lama-led government was no longer allowed to administer Kham, however. In the early eighteenth century, Kham was placed under Sichuan's oversight, and the Qing sought to undermine Lhasa's influence by controlling the appointment and review of local Khampa secular rulers (tusi). These rulers were to be selected based on imperial guidelines, but, as Xiuyu Wang notes, local custom continued to dictate power configurations. Local rulers also continued to monopolise control over land, law, and, through their personal militias, the use of force. In other areas of Kham, Tibetan Buddhist leaders held power, and monastery heads sought to monopolise the rights to collect taxes and adjudicate legal matters. ${ }^{(23)}$

At times, pluralist approaches to empire were challenged by men who envisioned the extension of uniform, central government institutions over frontier peoples. Often those proposals were accompanied by plans for Han colonisation or programs for assimilating non-Han peoples. Thus, there was disagreement over pluralist policies, but these issues were usually contested in debates over South and Southwest China, not Inner Asia. ${ }^{(24)}$ Not until the Daoguang era (1821-1850) were there serious challenges to the ideas of pluralism in Inner Asia. In the aftermath of rebellion in southern Xinjiang, influential proposals were offered by Gong Zizhen and Wei Yuan, who argued for transforming Xinjiang into a directly administered province colonised by people from China proper. When Zuo Zongtang argued for provincialising Xinjiang in 1877, he drew from these earlier writings to offer a new vision of governance. ${ }^{(25)}$

\section{The case of Xinjiang}

For over a decade beginning in 1864, Xinjiang was beyond the reach of the Qing central government. Internal rebels and an invasion by Yaqub Beg's Khoqand troops destabilised the regime and left it open to British intrigues and a Russian occupation of Yili in the far northwest. As Zuo Zongtang's armies sped westward in 1877, driving before them Yaqub Beg's rebel troops, the great statesman was already laying future plans. On 26 July 1877, Zuo sent the first of five memorials requesting provincehood for Xinjiang. Thus began a five-year period of discussion and planning in which the Qing court examined support for and against the proposal. Ultimately, a plan for provincialisation - but not Zuo's plan - was implemented in 1884. Several aspects of this process are intriguing, including the initial institutions designed to stabilise post-war Xinjiang, the debate over Xinjiang's future, and the ultimate plans for non-Han inhabitants.

The initial institutions for stabilisation were Reconstruction Bureaus (shanhou ju), managed by Liu Jintang, Zuo's close confident and fellow Hunanese. Both Zuo and Liu seem to have envisioned these Bureaus as institutions for change. Zuo identified Reconstruction Bureaus with "the belly lands" (fudi, China proper), perhaps because he had dealt with them as Governor General in Zhejiang after the Taiping rebellion. However, the Reconstruction Bureaus in Xinjiang differed from those with which Zuo had earlier experience. In 1860s Zhejiang, local elites took part in establishing Reconstruction Bureaus and pursuing the welfare and political processes necessary for recovery. In time, the Bureaus were transformed into more permanent "united welfare agencies" run by local elites who were increasingly active in managing their communities. In other words, the Reconstruction Bureau and other post-rebellion institutions became arenas in which local elites, who were influenced by "statecraft" scholarship emphasising activism in service of the state, began to claim responsibility for and power over important governing processes. ${ }^{(26)}$

Zuo was also a student of statecraft thinkers such as fellow Hunanese Wei Yuan (1794-1856), who supported the broadening of political participation in the name of statestrengthening; however, Wei's definition of those who should participate was limited to urban literati qualified for official bureaucratic positions. ${ }^{(27)}$ Whether Zuo had Wei's concepts in mind or not, his orchestration of the Xinjiang Reconstruction Bureaus initially paralleled Wei's ideas. Following orders from Zuo, Liu Jintang dispatched a network of expectant officials, men who were candidates for official

22. Luciano Petech, China and Tibet in the early XVIIIth century, 2nd rev. ed., Leiden, E. J. Brill, 1972, pp. 8-16, 78-79, 151-157, 223-224, 230

23. Xiuyu Wang, "China's Last Imperial Frontier: Statecraft and Locality in Qing Kham Tibet, 1890-1911," Ph.D. dissertation, Carnegie Mellon University, 2006, pp. 93-97, 100-110, 115.

24. For coverage of these debates, see John Robert Shepherd, Statecraft and Political Economy on the Taiwan Frontier, 1600-1800, Stanford, Stanford University Press, 1993 , pp. 137-154; Sutton, "Ethnicity and the Miao Frontier," p. 219; Giersch, Asian Borderlands: The Transformation of Qing China's Yunnan Frontier, Cambridge, Harvard University Press, 2006, pp. 89-91.

25. Millward, Beyond the Pass, pp. 246, 249-251

26. Rankin, Elite Activism, pp. 94-95, 106, 109-110, 119-120.

27. Philip A. Kuhn, Origins of the Modern Chinese State, Stanford, Stanford University Press, 2002, pp. 27-53. 
positions in China proper, into the areas that had to be rebuilt, and these men, linked through a hierarchy of Reconstruction Bureau networks, engaged in humanitarian efforts: settling refugees back on the land, rebuilding the agrarian economy, and ensuring supplies for the army. They were also authorised to inspect agricultural lands, rebuild granaries and communications infrastructure, and catch rebels - responsibilities clearly designed to take power from local elites, especially the begs of southern Xinjiang. While the begs were conceived of as important to certain processes, such as urging people to pay taxes, they were stripped of actual powers, such as the right to collect taxes. The Reconstruction Bureaus thus brought Han officials and law to areas that had previously been subjected to "pluralist" approaches. Zuo's goal seems to have been to use Reconstruction Bureaus as a step toward provincialisation. ${ }^{(28)}$ The Reconstruction Bureaus were temporary, and Zuo knew he had to convince the court to implement permanent provincial-style administration, but he faced opponents. One of the more experienced was Li Yunlin, a bannerman with experience in Xinjiang. Li's reports emphasised the devastation wrought in Urumqi and other regions: few banner armies and Han settlers survived the years of rebellion. The economy was devastated, the markets overgrown. Without Han subjects ( $\mathrm{min}$ ) to pay taxes, $\mathrm{Li}$ argued, it was impossible to establish counties, let alone a province. ${ }^{(29)}$ Li's emphasis on Han subjects as the foundation for provincial-style government was both practical and conceptual, for it reflected enduring political beliefs held by many bannermen: different "types" (zhonglei) of people required different forms of government, and the provincial or county system was suitable only for "migrant subjects from the interior (neidi qianju zhi min)." ${ }^{(30)}$ In the wake of the unrest, Li estimated that fewer than 5,000 Han households still inhabited Xinjiang, a "total not even equal to a county in China proper." Historian Sudebilege characterises Li's opposition, which was shared by others, as support for returning to older approaches more in tune with local customs (yinsu er zhi), and the court adopted this scepticism by questioning the viability of the provincial structure. ${ }^{(31)}$

Over the next several years, Zuo and his Hunanese associates, Liu Jintang and Tan Zhonglin, hammered away at their critics, developing a series of arguments that would shape Xinjiang's future. Drawing in part from Wei Yuan, Zuo emphasised strategic defence, internal governance, and fiscal discipline, but he embedded in his arguments certain crucial discourses about cultural difference and historical legitima- cy. ${ }^{(32)}$ As he had in 1875 , when some challenged the recovery of Xinjiang, Zuo defended the region's strategic importance: Xinjiang protected Mongolia, which in turn protected the capital district. Xinjiang's loss would jeopardise the entire empire. ${ }^{(33)}$ Due to the contemporary international climate, many believed this. The nineteenth-century "Great Game" brought Russian and British pressure on Inner Asia, and Russia had occupied part of Xinjiang in 1871. To avoid further encroachment, Zuo believed, the Qing should eradicate earlier ruling methods, which weakened the state. When local headmen (begs, jasaks) served as middlemen between the state and its subjects, Zuo argued, their corruption undermined state power. To overcome this, the state should dispatch district magistrates to provide a direct link between state and people. Explicit in Zuo's argument was the idea that both the structure and cultural content of China proper's governing institutions were superior. Zuo noted that regions where "governance according to local traditions [was implemented] were unable to follow the same traditions [practiced] in China proper," and he opposed this. ${ }^{(34)}$ In Zuo's mind, moreover, the Qing must strengthen state capacity and oppose foreign infringement, because China had maintained a position in Xinjiang since the Han period, and he thus believed it to be "our ancient soil" (wo jiutu). ${ }^{(35)}$ In the coming years, Zuo's protégés, Liu Jintang and Tan Zhonglin, provided positive news about Xinjiang's economic recovery as well as the possibilities for assimilation (xianghua) by Xinjiang peoples. ${ }^{(36)}$ The opposition to provincialising Xinjiang was ultimately overcome, and a modified proposal to link the new Xinjiang Province to Gansu was approved. Xinjiang would become a province. Historians have assessed these changes as monumental, with James Millward recently suggesting that the decision on

28. Zuo Wenxiang gong quanji (shudu), juan 19, p. 49, cited and discussed in Sudebilege, Wan Qing zhengfu, pp. 52-54.

29. Li Yunlin, Xichui shilue, "Wuyuan tutan," pp. 20-22, "Yingwu kongxu," pp. 22-23.

30. Li Yunlin, Xichui shilue, "Shanhou fanglue," pp. 30-35.

31. Sudebilege, Wan Qing zhengfu, pp. 53-55

32. These arguments, including Zuo's debt to Wei Yuan, are found in Nailene Josephine Chou, "Frontier Studies and Changing Frontier Administration in Late Ch'ing China: The Case of Sinkiang, 1759-1911," Ph.D. dissertation, University of Washington, 1976, pp. 221-244. See also Millward, Beyond the Pass, pp. 241-251.

33. For a recent summary of the 1874-1875 debate, see Ho-dong Kim, Holy War in China: the Muslim rebellion and state in Chinese Central Asia, 1864-1877, Stanford, Stanford University Press, 2004, pp. 161-163.

34. Zuo Wenxiang gong quanji, vol. 3, Taipei, Wenhai chubanshe, 1964, juan 53, 30a-39a.

35. Zuo Wenxiang gong quanji, vol. 3, juan 51, pp. 17a-19b.

36. Liu Xiangqin gong zougao, vol. 1, Taibei, Chengwen chubanshe, 1968, juan 3, 44. 
Xinjiang (and subsequent provincialisation of Taiwan in 1887) "demonstrates that provincialisation of the frontier, with the concomitant promotion of Han migration and implementation of Chinese institutions in areas with sizeable non-Han populations, was part of the beleaguered dynasty's attempt to shore up its position on all frontiers." (37) There was an alleged shift in approach, away from adjusting administration to local customs and towards the reproduction of China proper's institutions and culture. Liu Jintang, for instance, not only sought to remove Turkestani begs from power, but envisioned a comprehensive schooling system designed to teach Han language and culture. But was the provincialisation of Xinjiang such a seminal turning point?

Zuo and his Hunan compatriots had won a political battle to impose their vision on one Inner Asian territory. To do so, they had mobilised important rhetorical strategies, arguing for Xinjiang as ancestral land and for the inherently corrupting nature of hybrid institutions managed by cultural others. Both were important, but not unprecedented, developments in conceiving of region and empire. In earlier times, it was common for the Yongzheng emperor and his confidantes to deplore the corruption of culturally-other indigenous leaders as part of their plans for replacing them with Han magistrates. ${ }^{(38)}$ From this perspective, Zuo's arguments do not appear entirely novel. However, there is some evidence that larger contingent and cognitive processes were at work in the 1870s.

Neither Liu Jintang nor his successors were fully able to implement their plans. They denied local elites a legitimate role in political change, but were unable to remove them from the scene; however, they created an environment in which local elites actively opposed some imperial policies. Turkestani Muslims, for instance, resisted compulsory Chinese schooling and kept their boys away from the new institutions. In later decades there would be more resistance to taxes, schools, and the corruption of Chinese officials. By provincialising Xinjiang without providing legitimate roles or benefits for local elites, the Qing state created specific points around which opposition could rally. Meanwhile, the events seem to have provoked some thought about Islam and the state in China proper. The contemporary newspaper Shenbao covered Xinjiang events and openly questioned whether Muslims undermined the type of cultural and religious unity that made states strong. ${ }^{\left({ }^{39}\right)}$ Even though some began to question the place of Muslims in the state, the process of rebuilding Xinjiang actually allowed Turkestani settlers more freedom to move from the south into other parts of Xinjiang, thereby enlarging their demographic foot- print. In later decades, we are told, this would aid in developing a sense of ownership over the entire territory. ${ }^{(40)}$ Meanwhile, Zuo's proposals, which were not based on radically new arguments, had met with an opposition whose methods of thinking - about rulership, territory, and empire - did not disappear overnight. Xinjiang provided potential lessons for other frontiers, but this was not the beginning of an inevitable process of transforming the frontiers into Chinese provinces.

\section{Mongolia and Tibet}

One lesson from Xinjiang manifested itself in an awareness of how foreign powers might manipulate frontier peoples. When Russia occupied parts of Xinjiang and negotiated with Yaqub Beg, officials began to see Central and South Asia as sources of European threat. Zuo Zongtang, for instance, feared British incursions from India, and he warned that the British strategy towards China's inland frontiers, where they sought to control territory, differed from their approach to the coast, where they sought to control trade. ${ }^{(4)}$ In the minds of many, strategic vulnerability was linked to the weakness of Qing state capacity. The need to build capacity sparked debate over revenue, and opponents repeatedly argued against provincialisation in regions without sufficient revenue, which, for many policymakers, meant Han settlers paying land taxes. Thus, talk of state capacity and revenue often led to discussions about colonisation or assimilating indigenous populations in the frontiers.

Beginning in the 1880s, these three interconnected issues strategic defence, revenue, and colonisation/assimilation were discussed in connection with Mongolia, although it was not until the first decade of the twentieth century, during the New Policies (xinzheng) era, that those discussions were translated into action. The British invasion of Tibet (1903 1904) and the Russo-Japanese war (1904-1905) added new urgency to the process. In each case, however, the specific policies for transforming Mongolia and Tibet were varied and piecemeal, suggesting a contested and contingent policy-

37. Millward, Eurasia Crossroads, p. 137

38. Madeleine Zelin, "The Yung-cheng Reign," in The Cambridge History of China, vol. 9, William J. Peterson (ed.), Cambridge, Cambridge University Press, 2002, p. 223.

39. “Lun Kashiga'er shi," Shenbao, Issue \#780, Nov. 11, 1874, p. 1.

40. Millward, Eurasian Crossroads, pp. 138-149, 151-152; Sudebilige, Wan Qing zhengfu, pp. 59-63.

41. For Yaqub Beg's foreign policies, see Ho-dong Kim, Holy War in China, pp. 138-158. For the lessons about Central Asia, see S. C. M. Paine, Imperial Rivals: China, Russia, and Their Disputed Frontier, Armonk, NY, M. E. Sharpe, 1996, p. 165. For Zuo's comments, see Zuo Wenxiang gong quanji, vol. 3, juan 51, 17a-19b. 
making process. Recent work by Dahpon David Ho is particularly incisive, stressing that the commitment to transforming Tibet, which culminated in the 1910 invasion of Lhasa, was not the outcome of coherent and well-planned efforts to strip political power from ethnic Tibetans. ${ }^{(42)}$ In Mongolia as well, policies of colonisation and provincialisation were subject to opposition and modification, with the unintended outcome that the Qing (and Republican government) found itself defending hybrid institutions.

The first successful proposal to change Mongolia was made by Cen Chunxuan in 1902. Cen acted in response to the threat of Russian aggression, and he proposed opening tracks of Mongol land to Han cultivation. Although Han settlers already leased lands in places such as Ulaanchab and Yekhe Juu Leagues, the approval of Cen's request represented a breakthrough. Previous Qing administrations had opposed Han migration to Mongol banner territories, but in 1902 such segregation policies were challenged as the court sought to stabilise its hold on the North. Land reclamation, it was believed, would bolster agricultural productivity, thus increasing revenue for both state and Mongol banners. In the mind of Yigu, the official sent to oversee reclamation, the plan would benefit impoverished Mongols while also allowing the state to increase fiscal and military capacity in this vital frontier. ${ }^{(43)}$

Mongol commoners and elites were less sure, and their resistance shaped the initial implementation of the new policies. While Yigu confidently created a General Bureau of Cultivation Affairs (kenwu zongju) in Hohhot and promoted settlement in Chakhar, his plans were thwarted in Ulaanchab and Yekhe Juu. In Chakhar, most Mongol banner leaders were appointed by the state, but in the other Leagues, the nobility was home-grown, and they opposed reclamation. Though their opposition may have been linked to financial interests, they deployed the language of pluralism to convey their dissatisfaction. They noted that Han settlers would threaten pastoral lifeways, a violation of the Qing policy of treating all subjects equally (yishi tongren). More direct resistance was offered by Mongol commoners, whose vigilante groups (duguilangs or "circles") were mobilised to resist the New Policies. In some cases, Mongol opposition was overcome, but the resistance was a significant reflection of widespread opposition. ${ }^{(4)}$

Reaction to the Russo-Japanese War produced new proposals for provincialising Mongolia; it also led to new methods of knowledge production as officials began to conduct surveys of Mongol peoples and lands. An early survey was conducted by Yao Xiguang, who spent three months in Inner
Mongolia assessing the prospects for land reclamation and mining as well as investigating possible sites for Han settlements. The survey provided the basis for Yao's proposal that Mongols be subjected to direct rule and their lands opened to further Han settlement. It also seems to have set a precedent in which the survey became an important administrative tool. Later, in 1906, the newly-reorganised Ministry of Dependencies (Lifan bu) dispatched officers to conduct investigations into Mongolia and Tibet. ${ }^{(4)}$ Thus, the Qing state was beginning to institutionalise new methods for collecting and producing knowledge about its peripheral peoples and their lands. While the state had collected information on its subjects and mapped its imperial lands for many decades, ${ }^{(4)}$ the surveys of the early twentieth century provided knowledge that was inserted into new conceptual frameworks.

In May 1907, Cen Chunxuan submitted the most important plan for provincialising Mongolia. ${ }^{(47)}$ Cen framed the value of Mongolia in historical terms, not unlike Zuo's approach to Xinjiang three decades earlier. However, Cen was no mere traditionalist, and he articulated a self-conscious rejection of earlier concepts of the state. In doing so, he argued that contemporary historical conditions were novel and that the state's goals must adapt. Within its "sovereign territory" (suo shu zhi di), the state must establish law, collect information about the territory, manage defence, and promote development. Although Cen claimed, as earlier Qing officials might have, that the state should concern itself with the people's livelihood (minsheng), he also revealed a modern concern with comprehensive territorial administration, noting that in "the lands under state jurisdiction...there can be no vacillation in power." The comment suggests that Cen conceived of ideal state authority as equally and consistently applied across all territories, with none of the unevenness or inconsistencies that earlier pluralist approaches allowed. To

42. Dahpon David Ho, "The Men Who Would Not Be Amban and the One Who Would: Four Frontline Officials and Qing Tibet Policy, 1905-1911," Modern China, vol. 34, no. 2, April 2008, pp. 211-212

43. Sudebilige, Wan Qing zhengfu, pp. 71-75; Mei-hua Lan, "China's 'New Administration' in Mongolia," in Mongolia in the Twentieth Century: Landlocked Cosmopolitan, ed. Stephen Ktokin and Bruce A. Elleman, Armonk, NY, and London, M.E. Sharpe, 1999, pp. 41-44.

44. Christopher P. Atwood, Young Mongols and Vigilantes in Inner Mongolia's Interregnum Decades, 1911-1931, Leiden, Brill, 2002, vol. 1, pp. 46, 63; Sudebilige, Wan Qing zhengfu, pp. 76-81; Lan, "China's 'New Administration' in Mongolia," pp. 41-44.

45. Sudebilige, Wan Qing zhengfu, pp. 87-95.

46. Giersch, Asian Borderlands, ch. 3; Hostetler, Qing Colonial Enterprise.

47. Cen Chunxuan, "Tongchou Xibei quanju zhuosi biantong banfa zhe" (Guangxu 33/4/2), cited in Qingmo Chuan Dian bianwu dang'an shiliao, ed. Sichuan sheng minzu yanjiusuo, Zhonghua shuju, 1989, vol. 3, pp. 921-926. 
accomplish this, Cen argued for the establishment of three provinces centred in Inner Mongolia, and an aggressive extension of land reclamation into Outer Mongolia. Migrants were to be recruited by merchants, who earned rewards if they met certain benchmarks in numbers of households settled, acreage reclaimed, or mines opened. For Cen, the goal was to create an integrated state administration overseeing a commercial economy that could support troops, and he seems to have imagined Han Chinese as the foundation of this system.

Mongols were not irrelevant, however. Although Cen envisioned them as a simple people ensnared by Tibetan Buddhist superstitions, he wished to begin transforming Mongol boys through schooling. Those who graduated from primary schools could attend middle school and be eligible, just like banner and Han students, for government appointments. This, Cen felt, would prevent Mongol boys from joining the monasteries, where their talents went to waste. Mongol boys might also attend military academies, which Cen envisioned as institutions for change throughout the troubled frontier regions - Mongolia, Tibet, and Kham. In contrast to earlier pluralist policies, which largely sought to segregate Mongols from China proper, Cen's plan, and the New Policies in general, were designed to integrate Mongols into a strong, new China.

Cen Chunxuan and Yao Xiguang were part of an effort to reorder Qing territory. Their goal was to militarise the northern boundaries of the empire, and in order to do so, they mobilised new administrative resources (the survey), envisioned new institutions of assimilation (schools), and proposed to eradicate the "informal arrangements [and] multiple sovereignties" that had once characterised Qing approaches to Inner Asia. Naturally, there was resistance, and that opposition, along with the 1911 revolution, made it impossible to create provinces in Mongolia. When the court circulated Cen's memorial, it found broad but not universal support. The vision of a pluralist empire was still strong, and opponents of provincial governance for Outer Mongolia cited its alterity and incompatibility with Chinese ways. ${ }^{(48)}$ Mongol nobles and commoners resisted as well, and this resistance forced the Qing to reassess. Instead of removing Mongol nobles from power, the Qing turned to them to implement its New Policies, including land reclamation, education, and taxation. As the state sought to increase capacity in Mongolia, it found - as Republican governments would - imperial institutions difficult to abandon. ${ }^{(49)}$ Nevertheless, the new thinking behind Cen's plan did lead to major changes. New state institutions, including schools, police stations, and telegram offices, were established, and the legal barriers that had segregated Mongols from Han Chinese were eroded. In 1910, the court allowed unrestricted farming throughout Mongolia, the contracting of pasture land, and intermarriage between Mongols and Han. Mongols were legally permitted to learn Chinese and use Chinese surnames, and during this period a new generation of Chineseeducated Mongols emerged. ${ }^{(50)}$

If the Mongolia case demonstrates the contingencies involved in provincialisation, then Greater Tibet reveals a remarkable dichotomy in approaches to changing Inner Asia. In the aftermath of the British Younghusband invasion, the Chinese press was awash in disaster scenarios. In October 1904, Liang Qichao's Xinmin congbao ran an article entitled "Grieving for Tibet" in which Tibet's future was envisioned as similar to those of the British protectorates in Nepal and Bhutan. ${ }^{(51)}$ The court responded to British pressure with efforts to clarify Tibet's status and transform the administration of Tibet proper and Kham.

In 1906, Zhang Yintang was dispatched to Lhasa to reinvigorate Qing authority. Zhang's approach was influenced by attitudes common among his peers such as Cen Chunxuan. Zhang felt that traditional Tibetan values were quaint at best, and more often dangerous. He critiqued polyandry and sexual promiscuity as immoral, trumpeted modern hygiene, urged new clothing styles to prepare Tibetans for productive work, and suggested that Chinese language be widely adopted. Zhang did not, however, seek to force these transformations through violence (or, at least, he seems to have reconsidered the use of troops), and Ho demonstrates how Zhang developed a number approaches for working with Tibetan leaders. Zhang apparently embraced certain Tibetan rituals, such as swearing an oath before the Buddha, and visited the Tibetan governing bodies to seek their support in transforming government. Warning that Tibet risked a fate similar to that of Bhutan and Nepal, Zhang recommend an alternative: Tibetan leadership should endorse political reorganisation along Chinese bureaucratic lines, and they should reform Tibetan customs. Zhang was apparently quite persuasive, and a proposal outlining these changes was sent, with Tibetan support, to Beijing in April 1907. ${ }^{(22)}$

Ho's evidence suggests that Zhang had identified an alternative to the Xinjiang and Mongol approaches. In Xinjiang
48. Lan, "China's 'New Administration' in Mongolia," pp. 45-50
49. Atwood, Young Mongols, pp. 39-40, 46; Bulag, "Going Imperial," pp. 261-262
50. Lan, op.cit., pp. 45-50
51. Xinmin congbao, no. 55 (year 3, 7 qi, 0ct 23, 1904 [Guangxu 31/9/15]).
52. Ho, "The Men Who Would Not Be Amban," pp. 215-220. 
and then Mongolia, the Qing sought, albeit unsuccessfully, to exclude Turkic begs and Mongol nobles from state-building and transformation processes, but Zhang seems to have included Tibetans in decision-making and to have encouraged, however insensitively, voluntary changes in everyday practice. ${ }^{(3)}$ As Qing officials sought to re-conceive their state, many shared the conviction that new centralising administrative technologies and the transformation of frontier peoples' lifestyles were necessary. Yet, there were divergent approaches to implementing such changes. Zhang's approach in Tibet proper, for instance, differed from Zhao Erfeng's use of intense violence in Kham.

By the early twentieth century, imperial power in Kham had deteriorated, and after 1904, as the Qing sought to reassert power, Khampas resisted. State efforts to control land and encourage reclamation provoked the assassination of the assistant imperial resident. The perpetrators felt the act to be justified because they were seeking to protect local livelihoods and religious autonomy. In response to Khampa resistance, the Qing sent Zhao Erfeng to Sichuan. Arriving in 1905, Zhao sought to impose state control over resources, taxation, law, and coercive force. To do so, he used largescale violence. In effect, his goals were the same as Cen Chunxuan's in Mongolia or Zhang Yintang's in Tibet proper: to reorient the political, cultural, and economic landscape. In regions where secular hereditary rulers (tusi) held power, Zhao replaced them with Han officials. In regions where Tibetan Buddhist monastic authority was strong, Zhao banned monastic participation in government and legal affairs. Monasteries suspected of anti-Qing activities were stripped of their lands. This process met with popular resistance, but Zhao persisted in trying to transform the relations of power and patronage that linked monasteries to local communities. To further this, the Qing restructured the legal system so that Han officials alone had the authority to settle disputes, and Zhao implemented new regulations to discipline Khampas by criminalising certain traditional practices. $\mathrm{He}$ also promoted colonisation by wresting control of land from local institutions and providing it to Han military or civilian settlers. ${ }^{(54)}$

Thus, there were two different approaches to dealing with Greater Tibet by 1907. Coercion and violence characterised Zhao's removal of indigenous rulers in Kham, while Zhang, despite his disdain for Tibetan customs, apparently pursued a policy of negotiation and coercive persuasion. Both men sought to transform Tibetan society and monopolise for the central state the right to increase revenue, develop the economy, and dispense justice, but Zhang Yintang provided space for the indigenous elites to join this state-building initiative. In Ho's account, British observers found both approaches to be effective, but their successes were quickly jeopardised by the imperial resident, Lianyu. Ho depicts Lianyu as a manipulative official who orchestrated Zhang's removal from Lhasa, tried but failed to bring Zhao Erfeng to replace him, and then helped talk the court into invading Tibet proper in 1910. Each step increased the tensions between Tibet elites and the Qing. Known as the "Butcher," Zhao was not welcome in Lhasa, and the Dalai Lama sent angry letters of protest to the court. When Qing troops marched on Lhasa, the Dalai Lama was promised a peaceful occupation and a preservation of his spiritual powers, but Lianyu mobilised his own soldiers to attack monasteries, thus touching off violence as well as the flight of the Dalai Lama to India. Lianyu's goal may have been to intimidate and weaken Tibetan power-holders, but his decisions had extraordinary implications: Ho identifies these incidents as the first steps toward the violence and enmity that would poison the Sino-Tibetan relationship throughout the twentieth century. ${ }^{(55)}$

These new accounts of early twentieth-century Kham and Tibet suggest that while many imperial officials shared a vision of modernising Beijing's relationship with Tibet, there were different approaches to implementing sovereignty in these far-flung imperial frontiers. While the goal was to increase or even transform state capacity in order to protect against foreign imperialism and assert greater authority over the political and cultural apparatuses, there was room for an inclusive strategy that sought cooperation with Tibetan elites. In Mongolia and Xinjiang, too, some had questioned policies that replaced the pluralist institutions led by indigenous elites with Han-dominated provincial-style government, and ultimately the state could not bypass Mongol nobles. In each case, however, the Qing state, despite its history of flexibility in Inner Asia, still tended toward approaches that excluded, alienated, or undermined local elites.

These examples stand in contrast to case studies from contemporary China proper. In North China, conditions resembled those found in Inner Asia. In the aftermath of the Boxer uprising, the state faced foreign occupation, and in response, officials such as Yuan Shikai sought to reassert imperial authority and build state capacity. To do this, Yuan

53. Even the British representative in Lhasa, Sir Charles Bell, grudgingly acknowledged Zhang's initial popularity with Tibetans. Tibet, Past and Present, 0xford, Clarendon Press, 1924, p. 89.

54. Wang, “China's Last Imperial Frontier," pp. 118-119, 127, 188-202, 210-212.

55. Ho, "The Men Who Would Not Be Amban," pp. 225-242. 
sought new revenue sources, revamped local administration to strengthen imperial magistrates, and organised new institutions of control, such as police forces, to extend government capacity at the local level. ${ }^{(56)}$ As this process unfolded, Yuan developed good working relationships with local elites. He supported reforms that were attractive to them, such as new educational institutions. Even though the extension of state capacity was geographically uneven, Stephen MacKinnon believes that Yuan was relatively successful in promoting reforms and appealing to local elites. ${ }^{(57)}$

A slightly different view of state-elite relations emerges from Mary Rankin's work on Zhejiang. In the 1860s, there were important changes in relations between social leaders (a "managerial elite") and the bureaucratic state. Local elites expanded their activities and networks as they managed reconstruction and relief efforts after the Taiping uprising. Initially, elite managers did not consider their activities to be a challenge to the state, but a contribution to good governance. By the 1890s, these elites were politicised by the Sino-Japanese war, and their concerns began to be directed by a growing nationalism expressed through reformist journals. Thus, just as the state sought to increase its capacity at local levels - through the New Policies that influenced changes in Zhili and Inner Asia as well - managerial elites called for reform in government, including greater elite participation. In Rankin's view, this demand for greater participation was largely met as new positions were filled by local elite managers. Even though the New Policies were intended to strengthen central government control over local society, they provided ways for local elites to expand their role and make increasing demands on the state. Thus, there were conflicts between state-building and social mobilisation of elites, but "both sides desired similar reforms to create a strong, wealthy, unified China." Only in the very late Qing did these mobilising elites turn against the court, a development that demonstrated that foreign pressure and the Qing's inability to protect China had convinced many elites that they were more qualified to lead the nation. ${ }^{(58)}$

In the cases sketched by MacKinnon and Rankin, local Han elites in China proper were included (or demanded to be included) in the processes of reform and state-building. Such inclusion gave them, Rankin argues, the space to take an increasingly active role in China's politics and to eventually demand control over China's fate. While neither work is a definitive study, both suggest that late Qing state-building included bargaining and contention with local Han elites, whether in Zhili or Zhejiang. In other words, the state was seeking to increase its capacity, but to do so it had to work through local elites - by providing some benefits and by allowing elite networks to direct some of the processes. Comparative studies demonstrate that it is precisely when states seek to increase capacity that they often must bargain with those who control resources, whether land, commercial wealth, or capital. ${ }^{(59)}$ In the case of Han elites in places such as Zhejiang and Zhili, the bargaining process seems to have given those elites a legitimate role and stake in the future of the state, even if the state was no longer run by the Qing court.

For elites in Inner Asia, however, late Qing state-building did not provide many legitimate roles. Many Mongol elites and commoners opposed the imposition of new administrative structures, and the state reluctantly delegated to the banners some responsibilities for its New Policies. Instead of providing Mongol nobles with an increasing legitimacy and stake in the future of the state, however, these roles either undermined them (in Inner Mongolia) or drove them to revolt (in Outer Mongolia). In both cases, the results were contrary to the original goals, and the unintended consequences would shape the future of Inner Asia-China relations. On one hand, there was the establishment of a new and independent theocratic state in Outer Mongolia. On the other, the new opportunities for integration with China gave rise to the "Young Mongols," a generation of revolutionaries whose experience in Chinese schools would nurture an ideology of Mongol "racial-revival" and a desire to increase Mongol control over developments in Inner Mongolia. ${ }^{(60)}$

Tibetan leaders may have had an early opportunity to "bargain" over their future, but the occupation of Lhasa destroyed this process and sparked the Thirteenth Dalai Lama's exile in India. After initially deposing him, the Qing then sought his return, but his response to the imperial resident in Lhasa was emphatic:

You are fully aware of this inexcusable illegal action taken by your troops; yet you inform me and my ministers that the situation...is peaceful. I know that this has been said to persuade me to return and also I know that it is false. Because of the above, it is not

56. Stephen R. MacKinnon, Power and Politics in Late Imperial China: Yuan Shi-kai in Beijing and Tianjin, 1901-1908, Berkeley, University of California Press, 1908, pp. 57-59.

57. MacKinnon, Power and Politics,p. 176.

58. Rankin, Elite Activism, pp. 18-19, 24, 27, 135, 170-172, 201, 228, 243.

59. Charles Tilly, "Reflections on the History of European State-Making." The Formation of National States in Western Europe, Princeton, Princeton University Press, 1975, pp. $37-$ 38; Tilly, Democracy, Cambridge, Cambridge University Press, 2007, pp. 33-40.

60. Atwood, Young Mongols, pp. 46-49, 81-82.

61. Cited in Melvyn C. Goldstein, A History of Modern Tibet, 1913-1951, Berkeley, University of California Press, 1989 , pp. 57-58. 
possible for China and Tibet to have the same relationship as before. ${ }^{(6)}$

In exile, the Dalai Lama reconsidered Tibetan commitment to a central Chinese state, and as the 1911 revolution erupted, he developed a War Department and trained soldiers who would drive Chinese troops from Tibet in 1912. Thus, late Qing developments led to Inner Asian elites taking very different stances on the concept of "China," just as they also led Han elites to develop new understandings of Inner Asia.

\section{Tibet in the media}

The social mobilisation of reformist elites in the late Qing was intertwined with the rise of new media. Journals containing new-style editorials focused on national affairs, and reformers used newspapers to instruct the public. No longer were the people, particularly the elite, to be passive in the face of national affairs. Even after the court censored reform journals in autumn 1898, crucial newspapers such as Xinmin congbao were established overseas. By this time, the idea of a nationally conscious public opinion had emerged, and writers encouraged broad political participation. ${ }^{(2)}$ The most important issues included sovereignty, territory, and nationalism, and the railway rights recovery movement, in particular, reveals how important the press, especially in Sichuan, was to nationalist activists. ${ }^{(63)}$ The same journals that focused on railroads also turned their gaze on foreign imperialist threats to Inner Asia, especially Tibet.

During the 1890s the volume of Qing writing on Tibet grew rapidly, and writers urged their reading public to be concerned about Russian and British imperialism as well as the state's capacity to develop Inner Asia's economy and transform its politics. ${ }^{(64)} \mathrm{A}$ brief survey of journal articles reveals writers urging the reading public to make various cognitive leaps, to acquire new perceptions about the political community called China. In Republican times, these efforts would become more sophisticated, but already people were asked to conceive of the frontiers as vital national territories, to see Inner Asian lands as China's historical soil, to learn about new methods for collecting knowledge, and to embrace Tibetans as fellow citizens who, while suffering under rapacious and devious lamas, required assimilation and economic development. In the process, these writers began to construct important and durable conceptions about Tibetan history, culture, and religion.

In their editorials, writers lamented foreign pressure on Tibet, and they developed an important symbolic vocabulary to explain why others should care, too. Some of the earliest analysis appeared in the Chengdu newspaper Shuxue bao, a publication associated with reformist ideas. In a June 1898 article, Wang Rongmao revealed his concerns about growing British and Russian influence in Tibet, and he urged a number of steps for securing the region. A first step was to acknowledge that earlier practices of pluralist rule were obsolete. To institute direct rule, Wang argued, would require new types of geographical knowledge, and he suggested as a model Western travel accounts and maps, which were precise in detail, particularly when it came to summarising regional products, local political conditions, and geographical features. With this knowledge, Wang implied, the state could increase security by planting farmer-militia colonies (tuntian), developing trade, opening mines, and moving Sichuan's poor in to build railroads. ${ }^{\left({ }^{(5)}\right)}$ Wang's article was an early one, but he revealed four concerns that would become more fully developed over the next decade: (1) identifying foreign threats as a means to construct Tibet as vital national territory, (2) emphasising the need for new forms of knowledge and institutions to reinvigorate decrepit imperial rule, (3) urging Han migration, and (4) planning for economic development and modern infrastructure.

Another early opinion piece in Shuxue bao contributed two other crucial themes: the use of domestic metaphors to help personalise the importance of Tibet for readers, and an attack on the Tibetan Buddhist hierarchy. The author, Chen Qichang, noted that the Russians and British might wrest Tibet from Qing control, leaving Sichuan province vulnerable. To make this concept more vivid, Chen described Sichuan as a courtyard and Tibet as the screen (waiping) protecting it from the street. Without Tibet, Sichuan was exposed to the outside world, and he therefore urged a policy that treated Sichuan and Tibet together. To do this, Chen recommended eradicating the Tibetan Buddhist hierarchy, although he did envision a future in which local Tibetan leaders emerged to manage their communities. ${ }^{(66)}$

62. Judge, Print and Politics, ch. 1; Rankin, Elite Activism, p. 169.

63. Rankin, "Nationalistic Contestation and Mobilization Politics: Practice and Rhetoric of Railway-Rights Recovery at the End of the Qing," Modern China, vol. 28, no. 3, July 2002, pp. 315-361; Danke Li, "Popular Culture in the Making of Anti-Imperialist and Nationalist Sentiments in Sichuan," Modern China, vol. 30, no. 4, October 2004, pp. 470-472.

64. Wang, “China's Last Imperial Frontier," pp. 67-68.

65. Wang Rongmao, "Tongchou Shu Zang quanju lun," Shuxue bao no. 4, June 1898 (Guangxu 24/4/xiaxun), in Qingmo Minchu Zang shi ziliao xuanbian 1877-1919, ed. Lu Xiuzhang, Beijing, Zhongguo Zangxue chubanshe, 2005, [Hereafter QMZS], pp. 2-3.

66. Chen Qichang, “Jing Zangwei yi gu Shujiang yi," Shuxue bao no. 10 (August 1898, Guangxu 24/6/xiaxun), in QMZS, pp. 3-6. 
Within a few years, stories about Tibet appeared in papers with national circulation. In April 1901, Qingyi bao ran a short story on Tibet's "strange customs" (qisu) as a means of familiarising its readership with Tibetan lands and peoples. ${ }^{(67)}$ The British expedition to Lhasa was covered in Shibao and Zhongwai ribao, and in October 1904, Xinmin congbao ran its story, "Grieving for Tibet," which traced increasing British and Russian imperialism in Central Asia and emphasised British transgressions against Chinese sovereignty, including the direct negotiations with Tibetan officials that produced the Lhasa Convention (1904). The story criticised the Qing state for its weak response and placed Tibet within a larger framework of "grieving" for all Inner Asian territories: the Japanese were threatening the northeast, the British Tibet, and the Russians, feeling out-manoeuvred by the other powers, would probably turn to Mongolia for compensation. The article further lamented the general public apathy toward Tibet, an attitude that allowed the British a strategic hold in the planet's highest region, from which they could influence Xinjiang, Sichuan, Yunnan, and through Tibetan Buddhism, Qinghai and Mongolia. ${ }^{(68)}$

In general, the coverage of Tibet followed the themes defined in the Sichuan papers and Xinmin congbao. Writers constructed Tibet as vital national territory using strategic and historically-based arguments as well as metaphors identifying Tibet as a "screen" or wall of the Chinese courtyard home. They urged fellow citizens to care about Tibet and to realise the need for collecting new geographical, economic, and political knowledge about it. Finally, they evaluated Tibetans and found them wanting. The Tibetan Buddhist hierarchy received the most criticism, but it was argued that Han, whether civilian or military settlers, should take responsibility for developing the Tibetan economy and peoples.

While writers portrayed Tibet's relationship with China as an historical one, they often argued that the contemporary era was qualitatively different than the past. This self-conscious awareness of living in a new age, moreover, underpinned arguments about transforming Tibet. In Dongfang zazhi, a 1906 proposal for provincialising Tibet noted that "since our dynasty entered Tibet, it did not change the governing institutions and it did not transform the religion...thus, Chinese sovereignty in Tibet had an undeserved reputation, and the lamas had the practical governing power..." ${ }^{\left({ }^{69)}\right.}$ This, it was argued, had invited British and Russians encroachment. Although Tibet had acknowledged allegiance to China for almost 300 years, the past could no longer guide the present - under current conditions, only the construction of direct rule through provincial institutions would save Tibet. In the
Datong bao, published in Tokyo, the Manchu Rong Sheng agreed that a new era had dawned, declaring the current age an "era of national imperialism" (guomin diguo zhuyi shidai) in which states conquered foreign territory and assimilated foreign races (yizhong). ${ }^{(70)}$ Rong believed China to be at a disadvantage in this pursuit, and this made him fearful for the future. China was, he suggested, like a courtyard dwelling; the imperialists were thieves seeking to climb the walls and plunder the house. Only by constructing strong walls in Tibet and Mongolia could China be preserved.

The concept of Tibet and Mongolia as "screens" or walls protecting China proper was widespread, and it harkens back to earlier concepts about the strategic necessities of the frontiers, including the role of Xinjiang protecting the empire, which had been sketched by Zuo Zongtang in the 1870s. ${ }^{(71)}$ But the metaphors of the 1900s were more immediate and intimate - China was a house threatened by bandits, or a body afflicted with illness, as Huang Yanchang suggested in the Chengdu provincial assembly's paper in 1910. ${ }^{\text {(72) }}$ To diagnose and treat an illness, Huang noted, the physician first inspects the patient, and he urged the Sichuan provincial assembly to serve as physician by sending a mission to Tibet. These intimate metaphors were designed to help readers imagine frontiers affecting their own lives. Huang linked the body metaphor to the political realities of his time, arguing through his title that he was concerned with issues of life and death (cunwang); more specifically, the new assembly was responsible for protecting Sichuanese livelihoods, but security in Sichuan was impossible without a defence of Tibet. Huang's plea included a short history of failed Qing policy toward the frontiers, and he accused the state of being unconcerned about border security, noting that China had recently lost territory to the Russians (east of the Usuri River), the French (along the Laotian border), and the British (the Kachin Hills along the Burma border).

Huang's demand for an investigative mission reflected a growing interest in new types of knowledge often identified with Europeans. In a 1907 Datong bao piece, the author provided three withering critiques of Chinese approaches to

67. "Xizang fengsu," Qingyi bao, No. 76, 19 April 1901.

68. Xinmin congbao no. 55.

69. "Ni gaishe Xizang xingsheng ce," Dongfang zazhi (Disan nian, dier qi, 19 March 1906), in QMZS, pp. 156-160

70. Rong Sheng, "Jingying Meng Zang yi baozun Zhongguo lun (shang)," (Tokyo) Da tong bao (no. 7, 28 June 1908), in QMZS, pp. 48-64

71. For a brief discussion of frontiers as "screens," see Giersch, Asian Borderlands, p.62.

72. Huang Yanchang, "Lun ziyiju yi pai yuan diaocha Xizang yi jue cunwang wenti," Shu bao (diliu qi 2 Nov. 1910), in QMZS, pp. 106-110. 
Tibet: British missionaries were skilled Tibetan-speakers while no Qing officials spoke the language. Missionaries had detailed maps of Tibet, but military officers in Chengdu possessed none. Important Tibetan events were reported to the British consuls while the Chengdu civil officials remained ignorant. ${ }^{(73)}$ True or not, these arguments made a case for new forms of knowledge, a point made even more forcefully in Shubao by Huang Yanchang, who suggested that anyone wanting to investigate the state of Tibet was far better served by reading foreign reports in translation. ${ }^{(74)}$ While the Russians, British, and Japanese were secretly investigating Tibet, Huang continued, Chinese had done nothing. $\mathrm{He}$ therefore prioritised geographical knowledge, including locating transport routes, ascertaining altitudes, determining soil fertility, locating mountains and river drainages, and assessing the material conditions of people's lives.

If most writers were certain about Tibet's strategic value and its ancient connections to China, they were less certain about the place of Tibetan people in the nation. A 1906 proposal for provincialisation, published in Dongfang zazhi, characterised Tibetans as "foolish and dull." ${ }^{(75)}$ To change Tibet, it was argued, would require new human capital, and this plan called for Sichuanese to man new garrisons, open mines, and found schools. Only after Tibet was stabilised would there be time to focus on transforming Tibetans through education. This article envisioned a long process of assimilation as Tibetan students studied simple texts to teach them Mandarin and were slowly weaned from their religious superstitions, but it still held out hope that, "once they have assimilated to some degree, then [we can] use advanced education to make them purely assimilated."

While transformed Tibetan commoners were envisioned as future citizens, the Tibetan Buddhist clergy were excoriated for a perceived brutality toward their people and insubordination toward Qing authority. ${ }^{(76)}$ Writers frequently demonized lamas, particularly the Thirteenth Dalai Lama. Yuan Zhong complained that lamas wallowed in vice and corruption. He despised the large monasteries for their rich properties and usurious loans that led to enslavement of commoners. Like other writers, Yuan conceived of a Tibetan people as both blindly devoted to their religion and deeply unhappy with the Tibetan Buddhist hierarchy. More importantly for his audience, Yuan portrayed the Tibetan Buddhist clergy as traitorous for their connections to the British and Russians - an emphasis not unique to Yuan. Rong Sheng, for instance, vilified the Dalai Lama for seeking to expand his religious domain to include Tibetan Buddhists from India and Central Asia, a plan playing directly into the hands of the British and Russians. In other pub- lications, writers suggested methods for aiding Tibetan commoners in their escape from exploitation by the religious elite. ${ }^{(77)}$ The reform press presented ideas that reflected the concepts that drove Zhao Erfeng and his brutal transformation of Kham. Zhao seems to have detested indigenous political and religious institutions, which he felt were designed to keep ordinary people ignorant and to monopolize resources for a lazy and unproductive clergy. (While there was some truth to these beliefs, Zhao's claim to detest the brutality used against commoners did not prevent him from slaughtering Tibetans, too.) Like some in the reform press - and, decades later, Communist propagandists - Zhao created a simple image of a Tibet in which commoners were bitter and divided from their civil and religious governors. ${ }^{(78)}$ This image justified his efforts to eradicate indigenous ruling traditions and cultural practices, but these acts provoked chains of events that would make Kham a violent place for years to come.

\section{Conclusions}

Beginning in 1877 , there were numerous proposals for increasing state capacity in the Inner Asian territories. Most were designed to replace hybrid institutions with direct administration resembling the provinces and counties of China proper. Many plans were also designed to encourage Han migration and to transform non-Han people. However, these programs do not represent a single cohesive, long-term effort to transform Inner Asian realms into China proper. Zuo Zongtang's understanding of state-building was based on late imperial concepts and institutions. He mobilized qualified literati (often from Hunan) to staff his Reconstruction Bureaus, and he legitimized his approach through reflections on the relationship between ruler and subject. A strong state relied on qualified civil servants who were less inclined towards corruption than indigenous elites. A strong army drew its resources from Han settlers who cultivated the land and paid taxes. In many ways, his thinking mirrored that of the Yongzheng era, when the emperor sought to standardize the governance of his realm by reforming finances and removing non-Han aristocratic rulers from their place of mediation between frontier peoples and state.

73. Yuan Zhong, "Xizang," Da tong bao no. 2 1907-8-5 (GX 33/6/27), in QMZS, pp. 28-32.

74. Huang Yanchang, "Lun ziyiju yi pai yuan diaocha," pp. 106-110.

75. "Ni gaishe Xizang xingsheng ce," pp. 156-160

76. Wang, "China's Last Imperial Frontier," p. 159.

77. "Lun zhi Xizang shanhou zhi ce," Guangyi congbao (no. 229), in QMZS, pp. 97-99.

78. Zhao Erfeng memorial cited in Qingmo Chuan Dian bianwu dang'an shiliao, vol. 3, pp. 920-921. 
In contrast, the men who came later, such as Cen Chunxuan, operated under a different set of ideas. They self-consciously imagined themselves to be living in a unique era in which the justification for building state power, which included removing hybrid elites, had more to do with new spatial concepts of the state rather than older concepts of ruler-minister-subject relations.

The policies of provincialising Inner Asia were formulated and implemented in piecemeal fashion. In every case, the proposals were challenged and modified in the face of opposition from other policymakers and from people in affected territories. These contingent processes should be further scrutinized, because they reveal both different possibilities for dealing with Inner Asian elites and many unexpected outcomes. In Xinjiang, land reclamation projects did not attract enough Han settlers, but they did induce Turkestanis to move to new areas, a process that would later help bolster "Uyghur" claims to Xinjiang as a homeland. In Mongolia, the intricate processes put into motion by land reclamation and state-building affected Mongols in different ways, depending on where they lived and who they were. Some older elite groups, those most likely to have accepted their status as Buddhist Mongols under the Qing, rebelled to create their own empire in Outer Mongolia. New Chinese schools provided the environment for the rise of a new intelligentsia, who identified with China but also developed a strong sense of Mongol identity. In Central Tibet, the initial possibilities for elite involvement gave way to the violence and treachery of Zhao Erfeng and Lianyu. Such experiences drove the Thirteenth Dalai Lama into exile, where he developed ideas about establishing Tibetan autonomy.

The comparative study of state-elite relations is therefore a promising arena of inquiry for understanding the backgrounds and experiences of significant groups who would influence the course of twentieth-century events. It is important to realize that there emerged, for the first time in the late Qing, a significant conception of asymmetry between Inner Asia and China proper. Mongol, Tibetan, and even Turkestani elites were perceived as vital elements within the pluralist empire, which sought to segregate, as best it could, its various territories and peoples from each other. The policies of the early twentieth century emphasized integration, not segregation, and exclusion of hybrid elites from legitimate participation in the state-building process. This exclusion was not irreversible; the Republican state would still find it necessary to "go imperial" by attracting the support of Mongol and other non-Han elites. ${ }^{(79)}$ The process of exclusion did, however, lead significant groups in Mongolia and
Tibet to reject older alliances with the Qing, perhaps finding it difficult to conceive of their future in China. In contrast, Han elites entered a new era in which they exercised more authority, bargained with the state, and ultimately asserted their right (along with revolutionaries) to wrest China from the Qing.

In the process, moreover, the journals that reflected and influenced Han reformist thought began to emphasize the new, asymmetrical relationship between China and Inner Asia. If the creation of modern states is, in part, a cognitive process, then the late Qing is the place to look for the origins of a modern China that includes Inner Asia as a junior partner in the nation. Journalists mobilized new metaphors to encourage the reading public to care about Tibet, and they endorsed new methods for producing knowledge that would extend state power over non-Han people. They also developed discourses - of Tibetans in need of saving from their superstitions, of the need for Chinese to develop the Tibetan lands and economy - that now appear durable. One need not look any further than the March 2008 disturbances in Tibet to find related discourses, in state newspapers and some blogs, that demonised the Dalai Lama, urged increased exclusion of Tibetan elites from legitimate roles in the region's future, and criticised ordinary Tibetans for being ungrateful for all that had been done for them. In the aftermath of these tensions, it may be best to remember Zhang Yintang or those who opposed the eradication of hybrid institutions, for a study of the late Qing reveals, somewhat seductively, that there are other possible paths into the future.

\section{Glossary}

cunwang 存亡・Datong bao 大同報・Dongfang zazhi 東方雜誌 fudi 腹地 - guomin diguo zhuyi shidai 國民帝國主義時代 junxian 郡縣・ kenwu zongju 墾務總局 - Lifan bu 理藩部 min 民・ minsheng 民生・ neidi 內地 neidi qianju zhi min 內地遷居之民・ qisu 奇俗 shanhou ju 善後局・Shenbao 申報・ Shuxue bao 蜀學報 suo shu zhi di 所屬之地 - tuntian 屯田 - tusi 土司 - waiping 外屏 wo jiutu 我舊土 - xianghua 向化 - xing 性 - xingsheng 行省 Xinmin congbao 新民叢報・ xinzheng 新政 yinsu er zhi 因俗而治 - yishi tongren 一視同仁 yizhong 異種 - zhonglei 種類

79. Bulag, "Going Imperial." 